Anderson, V. (2017) HRD standards and standardization: where now for human resource development? Human Resource Development International http://dx.doi.org/10.1080/13678868.2017.1321872

\title{
HRD standards and standardization: Where now for Human Resource Development?
}

This paper examines standard-setting and standardization processes currently being undertaken in the Human Resources field and makes a 'call to action' for HRD scholars and practitioners to influence these developments. The paper provides a reflexive 'insider account' of HR standards development combining personal experience with theoretical perspectives; 'grey' and practitioner literatures; and secondary data sources. Drawing on scholarly literature sources opportunities and dilemmas of standardization processes in the HR field are discussed. Grounded in the standardization literature alternative approaches to system-wide (meta) standards are identified. Drawing on publically available information different standardization approaches in USA and UK are discussed. The paper critiques the dominant performance-orientated paradigm and 'rules based' approach to standards and argues for an alternative, principles-based approach for HR standardization to support sustainable individual and organizational performance. These issues have important consequences for HRD identity, pedagogy, education and practice. In addition to the development of an original typology of emerging HR standardization the paper contributes a new perspective to debates about the identity, values, purpose and contribution of HRD and the relationship between HRD and HRM.

Keywords: standards; standardization; meta-standards; Human Resource Development; Human Resource Management.

National and international standards and standardization represent a 'growth industry' (Brunsson, Rasche, and Seidl 2012). This paper examines standard-setting and standardization processes currently being undertaken in the Human Resources (HR) field and highlights the opportunity for those in Human Resource Development (HRD) 
to influence these developments. Standardization in the HR field has profound implications for HRD professional identity, practice, pedagogy and education and so an HRD perspective is required to influence these developments.

Although national-level Human Resource Development (HRD) standards, for example the UK Investors in People (IiP) standard, have been available for more than twenty years (Murphy and Garavan 2009) these standards have, thus far, been outside the remit of accredited national and international standardization bodies. Since 2009, however, standardization bodies such as International Standardization Organization (ISO); American National Standards Institute (ANSI) and British Standards Institution (BSI) have begun to develop HR standards, something that represents a 'new frontier' for the field. Standardization and organizational accreditation processes have important implications for HRD identity, practice, scholarship and education. In this paper I highlight the opportunity for an HRD contribution to influence the form and purpose of

standards in the HR field. Although the outcomes of such a process cannot be predicted, involvement in HR standardization processes by those in the HRD field is necessary to encourage the development of standards that acknowledge the importance of learning and development at individual and organizational levels as a feature of socially responsible work organizations committed to sustainable and inclusive performance.

\section{Terminology, Research Questions and Contribution}

In its focus on HR standards this paper acknowledges the enduring debate between scholars and professional organisations, such as Society for Human Resource Management (SHRM), the Association for Talent Development (ATD) and the UK Chartered Institution of Personnel and Development (CIPD) about the differences between HRD and Human Resource Management (HRM). The boundaries between these two fields remain unclear and contentious (Werner 2014; Reio 2013). However, 
contemporary standardization initiatives have shown that this debate has little resonance for practitioners. Standardization processes enacted by ISO, BSI and ANSI address HRM and HRD practices without distinguishing between them. In this paper, therefore, the term HR is used inclusively to connote practice concerned with people in work organizations, taking into account their management as well as their development (Werner 2014). Where the term HRD is used it refers to scholarship and practice focused on three principal constructs: people, learning and organizations (Sambrook and Willmott 2014) enacted through an occupational field that includes learning, training and development; adult and vocational education; management learning and organizational development (Hamlin and Stewart 2011).

This paper presents a reflexive 'insider account' of standards development (Lawless, Sambrook, and Stewart 2012). I have been involved in UK standards development processes for HR since 2013. As such it is important to acknowledge issues of 'cultural belongingness' in relation to interpretations of practice (Alvesson 2003). In order to avoid 'staying native' I aim to provide a reflexive account combining honest and descriptive reflection on personal experience of standardization with a pluralistic critique grounded in theoretical perspectives and further informed by 'grey' and practitioner literatures (Cotter 2014). The paper makes two contributions with specific relevance to HRD research and practice. First it offers an original analysis and typology of the emerging processes of standardization in the HR field focusing specifically on the distinction between rules-based and principles-based standards development. Second, in its focus on the potential influence of HRD to standardization processes, it adds to debate about the focus of HR standards and the relationship between HRD and HRM practice.

Three guiding questions inform the structure of the paper: 
(1) What factors have stimulated the trend to standardization in HR?

(2) What dilemmas do standardization processes present to the HRD field?

(3) How might, and why should, those in the HRD field contribute to the development of HR standards?

First, the trend towards standardization in work organizations and governance is examined to establish the context for standardization in the HR field. Second, drawing on the experience of national standards development processes that have been undertaken through the Investors in People (IiP) scheme over the last twenty years within HRD (Hoque 2008; Smith, Stokes, and Wilson 2014; Bourne et al. 2008; Gloster et al. 2010) the challenges and dilemmas associated with standardization are discussed. Building on frameworks developed within the standardization literature two alternative approaches to standardization are identified. First, the rules-based, normative and predictive approach is outlined which, proponents argue, provides a basis for the achievement of economic efficiency through compliance with established minimum threshold practices and procedures. Second, an alternative, principles-led approach is identified where standards are organized around a smaller number of ideas or values to provide a framework for thinking and decision about specific issues and a basis for flexible responses to emerging or special situations (Polacek, Gianetto, Khashanah \& Verma 2012). A comparison between the approaches to standards development of ANSI in USA and BSI in UK illustrates these different approaches. In addressing the third question the paper draws on the distinction between rules-based and principles-led approaches and argues for HRD informed principles to influence HR standards development processes to ensure recognition of the importance of learning and development at individual and organizational levels. Such involvement would 
legitimize developmental and sustainable organizational practices with potential benefits at individual, group, organizational and societal levels.

\section{Standards and Standardization}

Standards are explicitly formulated sets of consensual rules or guidelines aimed at achieving "an optimal degree of order in a current context" (Brunsson, Rasche, and Seidl 2012, p.613). A standard represents an "agreed, repeatable way of doing something" (British Standards Institution [BSI] 2017). This section addresses the first guiding question by providing a contextual background for contemporary HR standardization initiatives.

The influence of standards in organizational and social life has extended profoundly over the last century (Botzem and Dobusch 2012). Standards now influence market organization and affect benchmarking of products, services and organizational behaviours and practices (Brunsson, Rasche, and Seidl 2012). Initial standards served a technical design and manufacturing purpose, promoting design effectiveness, process efficiency and product quality assurance as a basis for product reliability and interoperability between components in supply chains. Over time, however, the purpose of standards has widened as accredited standardization organizations such as ISO, BSI, and ANSI have been established to develop and promote standards intended for diffusion and adoption by organizations throughout the world (van den Ende et al. 2012; Brunsson, Rasche, and Seidl 2012). Examples of the outcomes of such accreditation processes include the Quality Management Systems standard, ISO 9001, which has progressively influenced organizational, national and international practice.

Trends towards increasing institutional consistency have further encouraged a widening of scope and remit of standardization within operational management processes in organizations. Management system standards, referred to as 'meta 
standards' (Corbett and Yeung 2008) such as the ISO 14001 environmental management systems standard focus on organization-wide systems (Heras-Saizarbitoria and Boiral 2013) and provide the basis for wide-spread processes of auditing and evaluation of managerial practices. Proponents argue that meta-standards provide a basis for efficient and consistent operational management practices grounded in common, generically applicable institutional norms (International Organization for Standardization [ISO] nd). Critics of standardization, however, suggest that metastandards serve to inhibit organizational flexibility and innovativeness (Uzumeri 1997; Corbett and Yeung 2008).

In areas of professional practice the existence of national and international accredited standards also supports claims of professional integrity and status. Standards are a defining characteristic of professions in areas such as accounting, legal practice and health and social care (Kim, Park and Kolb 2014). Until recently the HR field has lacked any agreed standards of practice. Whilst research and discussion about policies, practices and processes are prominent in the HRM and HRD literatures, there has, until recently, been an absence of standards that guide and characterise the value and treatment of employees (Monks et al. 2013). Corporate scandals of the $21^{\text {st }}$ century, however, have increased interest in the grounding assumptions about the nature of 'human resources' and the way that people are managed and treated in work organizations (Guest and Woodrow 2012) leading to further interest in the development of HR standards.

To summarize, the current 'standardization turn' in HR is grounded in two important trends: first, the wider development of meta-standards covering system-wide areas of organizational and management practice, and second, an HR 'professionalization project' to counter criticism that HR practitioners lack any form of 
specialised competency, accountability and ethical framework (Watkins 2016;

Chartered Institute of Personnel and Development (CIPD) 2015; Westhuizen and Vuuren 2007; Guest and Woodrow 2012). In this context the development of standards to provide a benchmark for professional formation and assessment of HR practitioners' knowledge and behaviour (Ulrich et al. 2013) is viewed as a basis from which to assert the value-creation role of the HR function (ISO 2014; Cascio and Boudreau 2014).

Contemporary HR standardization processes were first initiated in USA in 2009 when ANSI, the American accredited standardization body designated SHRM as the exclusive developer of HR standards in USA (Jacobs 2013). Two years later ISO ratified a proposal for the creation of International HR standards and an ISO Technical Committee, TC-260, was established. By 2017 forty-nine countries were involved either as representatives or observers on this committee (ISO n.d). Alongside the work towards HR standardization in USA and at an international level, National level standards development processes have also been initiated in UK and elsewhere. In UK a BSI committee, HCS/1, was established in 2013 (Wong 2013) leading to the publication in July 2015 of BS 76000 Human Resource - Valuing People - Management System. Initial HR standardization processes have not been without controversy, however (Jacobs, 2013) and the next section examines the dilemmas confronting the HR field.

\section{Standardization: a dilemmatic issue}

The HRD field can claim to have led the way towards national level standardization in HR. In UK in 1991 the Investors in People (IiP) national standard was launched by the UK Government which has subsequently been adopted in at least twenty countries including Australia, France, Germany, Japan, the Netherlands, Sweden and South Africa (Bourne et al. 2008; Hoque, Taylor, and Bell 2005; Bell, Taylor, and Thorpe 2002, Murphy and Garavan 2009). Assessments of the effect of this initiative, 
drawn from the scholarly literature base, suggest five dilemmatic issues which are pertinent to the current 'standardization turn' in HR. These dilemmas relate to: the purpose and focus of standards in the HR field; the organizing principles of standards; the content and level of detail appropriate in any HR standard; the time horizon assumptions of standardization; and issues associated with risk; flexibility and innovation.

The first dilemma relates to the purpose and intent of standards as understood by developers and by adopters. The IiP standard was not developed by a national accredited standardization body but was funded by the UK government and administered at local level by Training and Enterprise Councils and Local Enterprise Councils (TECs/LECs) under the supervision of a non-departmental government body licenced by the UK Department for Education and Employment (Alberga, Tyson, and Parsons 1997). Analysis of the rationale and purpose behind the initial development and subsequent re-development of the IiP National HRD standards indicates an explicit focus of standardization towards improving corporate performance (Murphy and Garavan 2009). However, claims about the link between standardization and organizational performance have proved difficult to validate and non-adopting organizations have drawn attention to the lack of a measurable link between the implementation of an HRD standard and improvements in levels of training and development; organizational effectiveness; employee retention and job satisfaction (Smith, Stokes, and Wilson 2014). In response to this critique IiP standards have been progressively revised (Gloster, Sumption, Higgins and Cox, 2010; Collins and Smith, 2004) to focus on more general 'people management' requirements. However, this broadening of scope has failed to address critiques about the time and the cost of accreditation processes as well as the bureaucracy and lack of flexibility that may result 
from adherence to a generic standard which may outweigh any process efficiencies achieved by standardization (Gloster et al. 2010). In addition, the development of IiP standards towards a general management focus has also weakened the claim of IiP standards to support the professional standards of HRD in organizations.

The second dilemmatic area relates with the organizational assumptions that meta-standards exemplify. Like other meta-standards the IiP standard is based on a functionalist managerial paradigm. This takes for granted the universal efficacy of a 'check-do-review' process enacted through regular audits to assess whether a minimum threshold standard of management practice can be demonstrated to have been achieved and maintained. This functionalist paradigm privileges hierarchical structures of authority and accountability in organizations. However, critics have highlighted 'decoupling conflicts' that result from this approach. Whilst organizational and management legitimacy are signalled through standards adherence, internal commitment by those lower in the organizational hierarchy who are responsible for the implementation of standards may be lacking. In other words a 'check the box mentality' promoting compliance may result in individuals and organizations 'engineering' their way around precise standards requirements leading to simultaneous non-compliance and compliance; a situation where claims that 'the rules' of a standard have been followed can be made even if the outcome has been at variance with the original intent of the standard. (Brunsson, Rasche \& Seidl 2012).

Third, the IiP standards framework illustrates a dilemma concerning the content and level of detail that is appropriate in any standard in the HR field. Although globalization processes increase 'structural equivalence', social cohesion and conformity leading to coercive, normative or mimetic pressures for standards adoption (Murphy and Garavan 2009; Muzio, Brock \& Suddaby 2013) there is no consensus that detailed prescriptions of activities within the HR field are equally relevant for 
organizations of different sizes and types across different geographical locations. The licencing of the UK IiP standard by twenty different countries in Europe and elsewhere supports the view that HR standardization is a normative feature of organizations seeking to respond to image management pressures and customer expectations (Hoque, Taylor, and Bell 2005). In addition practitioner bodies such as SHRM in USA argue that "about $80 \%$ of HR is HR, whether you're in US, India or the UK" (Jacobs, 2013, p. 1). However, the emerging field of National HRD demonstrates distinctive understandings of HRD in different parts of the world requiring different approaches towards people, learning and organizations (Hoque, Taylor, and Bell 2005; Thite 2013; Wang and McLean 2007). The difficulty of specifying generic and standardized practices that might 'travel' across different national and institutional boundaries (Zachmeier and Cho 2014) is acutely demonstrated by widely different patterns of adoption of the IiP standard across country regions, industry sectors and organizational types and size (Hoque 2008; Hoque, Taylor, and Bell 2005).

A fourth dilemma, particularly acute in relation to the HRD field, is the issue of time horizon and the extent to which standards requirements should focus on short-term or long-term processes. Analysis of the standards developed over the life-cycle of IiP indicate a focus on shorter-term operational management practices that can be evidenced and audited. However, HRD practices relate as much to a longer-term as a short-term time horizon in matters pertaining to employee growth and organization development (Hernandez 2012; Waite 2013; Anderson, Garavan, and Sadler-Smith 2014).

The final dilemmatic area that emerges from an analysis of the IiP standardization process is the issue of risk and flexibility and the tension between pressures for stability and sameness versus change, development and flexibility. Whilst a focus on practices 
specified by standardization bodies may provide a basis for organizational reputation, process efficiency and functional operational effectiveness (Brunsson et al., 2012; Swann, 2010) prioritization of stability and uniformity presents a challenge to those in organizations who are committed to individual and organization development, flexibility and change. Critics of standardization highlight that organizational sustainability requires attention to different objectives, risk and decision processes, and stakeholder perspectives (Waite 2013; Anderson, Garavan, and Sadler-Smith 2014).

In summary, although HRD has led the way in the area of National standardization the experience over a period of 25 years has demonstrated competing pressures relating to: the organizing principles and vernacular of standardization; the purpose and focus of standards; the level of detail and specificity required; the time orientation and the consequences for risk and flexibility.

\section{Wider debates about standardization}

These dilemmas are not confined to the HR domain. In recent years scandals in areas of corporate governance; corporate accounting; food safety; building and engineering; and information and communication technology have demonstrated that the existence of standards is no guarantee of effective or ethical organizational practice (Liu 2014; Institute of Chartered Accountants of Scotland (ICAS) 2006; Polacek et al. 2012). As a result critics of standardization highlight the dangers of the 'symbolic adoption' of standards leading to a situation where compliance is demonstrated but activity within organizations reflects unethical and inappropriate management and occupational practice (Agoglia at al. 2011).

In response to such critiques two alternative remedies have been put forward. One approach has been to call for a strengthening of audit processes through increased regulation to identify and rectify areas of non-compliance or 'token compliance' 
through firmer rules and standards (ICAS 2006). An alternative approach, more evident in parts of USA, UK, Australia and EU has been a call for a 'principles-based' approach to standards development. Those who advocate a principles-based approach argue for the identification of a smaller, core set of principles, ideas or values that apply more broadly within a profession but which require professional judgment consistent with the intent and spirit of the standards (Polacek et al. 2012). Rules based standards are characterised by detailed guidance and process prescriptions focused on the achievement of practice consistency upheld through 'standards-authority'. Those who argue for principles-based standards, by contrast, argue for a smaller number of principles and a focus on ideas, concepts, outcomes or objectives to provide a 'framework' for thinking and judgement.

Advocates of this latter approach point out the potential of principles-based standards to better incorporate the interests of different stakeholders. In any standards development process stakeholder engagement at the development and dissemination stages is the main source of their legitimacy (Botzem and Dobusch 2012). However, for rules based approaches the focus is on an audit of compliance to consistent (management) rules and practices (Botzem et al. 2012; Swann 2010; Djelic and Den Hond 2014). In adopting this approach rules based standards privilege the perspective and vernacular of auditors, managers and standards specialists but give less attention to the perspectives of stakeholders such as customers, suppliers and those who work on behalf of the organization but are not in a formal employment relationship (HerasSaizarbitoria and Boiral 2013). In contrast, advocates of a principles-led approach to standards argue for standards that provide scope from which decisions and management processes can be determined in different organizational and cultural contexts (Agoglia et al. 2011). 
To summarise, the dilemmas associated with HRD standards illustrate the wider debates about standardization. The distinction between rules based, compliance orientated standards and principles-led approaches is summarized in Table 1.

\begin{tabular}{|l|l|l|}
\hline & Rules-orientated standards & $\begin{array}{l}\text { Principles-orientated } \\
\text { standards }\end{array}$ \\
\hline Purpose / focus & $\begin{array}{l}\text { Compliance } \\
\text { Good practice }\end{array}$ & $\begin{array}{l}\text { Excellence } \\
\text { Emergent practices }\end{array}$ \\
\hline Organizing principles & $\begin{array}{l}\text { Documentary evidence } \\
\text { Separate rules / clauses } \\
\text { Structured } \\
\text { Multi-stakeholder } \\
\text { Authority }\end{array}$ & $\begin{array}{l}\text { Integration around core } \\
\text { principles and values } \\
\text { Influence } \\
\text { Values-commitment }\end{array}$ \\
\hline Time-orientation & Short-term & Long-term \\
\hline Risk / flexibility & $\begin{array}{l}\text { Inflexible } \\
\text { Auditable } \\
\text { Stable }\end{array}$ & $\begin{array}{l}\text { Flexible } \\
\text { Innovative }\end{array}$ \\
\hline Content / detail & Many & Few \\
\hline
\end{tabular}

Table 1: Rules-based and principles-based standards

Table 1 indicates the difference between a rules based and principles-led approach to standardization and forms the basis for a comparison of the approaches to initial standards development undertaken by ANSI in USA and BSI in UK. In this section, in addition to a discussion of the approach taken by ANSI that draws on secondary sources available in the public domain I include my own personal experience of participating in the standards development process in UK to present a coherent approach of the process acknowledging that it is inevitably situated within a "network of multiple actors' (Spirakash and Mukhopadhyay 2015, p. 243). ANSI initiated standardization processes in association with SHRM in February 2009, an arrangement that lasted until 2016 (McIlvane, 2014). A number of task forces were established and contributions were invited from academicians and practitioners. In most cases the task 
force volunteers represented the interests of large corporations such as Intel Corporation; Microsoft China R\&D; Shell Oil Company; British Telecom and Time Warner Cable although the University of Central Florida and other academicians and consultants were also involved (Webster n.d; SHRM 2012). Secondary information sources in the public domain indicate a focus on standardization to establish a 'science or technology of HR' (Cascio and Boudreau 2014) as a basis for predictive 'best practice'-based standards to promote conformance, measurement, process consistency and cost reduction (Faragher 2012; SHRM 2012).

To achieve these aims a series of taskforces was established focused on standards development for: metrics and measures; compliance and regulation; employee and labor relations; staffing and workforce planning; performance management; and diversity and inclusion. By 2015 three ANSI standards had been published: 'Workplace Violence Prevention and Intervention' (2011) 'Cost-per-hire' (2012) and 'Performance Management' (2012) with subsequent work directed at: Workforce Planning, Job Descriptions, HR Metrics \& Reporting, Turnover Definition as well as three diversity related standards (Webster, n.d).

The development of British Standards has taken a different trajectory. A BSI committee was formed in 2011. As with all British Standards, BSI retained full control and responsibility for the development process and invited a range of stakeholders to be involved in the process. The standards development committee (HCS/1) included representation from organizations and employer bodies representing large and small organizations as well as those in public, private and non-profit sectors as well as consultancy, research organizations, 'think tanks', professional and scholarly associations such as CIPD and University Forum for HRD (UFHRD) and worker representation organizations. This plurality formed the context for my involvement in 
the process. As a representative of UFHRD on this body I moved, over a period of three years, from a position of an outsider on the committee to the position of an insidermember of the standards drafting sub-committee. Throughout this time I was never a 'full insider' and was conscious of my dual position as an academic professional representing a scholarly association as well as a standards developer.

The diversity of perspectives on the standards development committee led to extended debate about the title and purpose of the standard and the nature of the underpinning values and principles. After extensive debate in the drafting committee these were articulated as follows; each principal having equal value. First, people working on behalf of the organization have rights over and above the legal minimum; second, stakeholders and their interests are integral to the best interests of the organization; third, every organization is part of wider society with responsibilities for corporate citizenship and sustainable actions; fourth, a commitment to valuing people who work on behalf of the organization and to meeting the requirements of the standard is made and supported at the highest level (BSI, 2015). The focus of this standard, and of those subsequently developed by BSI in the HR field, is on the realization and value (actual and potential) of peoples' capabilities, skills, knowledge, experience, networks, behaviours, attitudes. The explicit purpose is to promote long-term organizational effectiveness, mutual respect of diverse contributions to organizational effectiveness and the importance of shared values and social sustainability. This represents a move away from a 'rules based' approach to standards towards an approach resembling the principles-based standards. Table 2 compares the ANSI and BSI approaches.

\section{Discussion}

This section addresses the third guiding question: how might, and why should, those in the HRD field contribute to the development of HR standards? In addressing 
this question I combine critical reflection on the standardization process from my 'insider /outsider perspective' with analysis of previous standards development work in the field, including the IiP standard and the work of ANSI and BSI. I argue that HRD perspectives are necessary to ensure that dilemmas identified from earlier experiences of standardization in the HR field are addressed.

\begin{tabular}{|c|c|c|}
\hline & ANSI & BSI \\
\hline $\begin{array}{l}\text { Committee / } \\
\text { task force } \\
\text { organization }\end{array}$ & $\begin{array}{l}\text { Delegated to SHRM } \\
\text { - Metrics and measures; } \\
\text { - } \text { Compliance and regulation; } \\
\text { - Employee and labor } \\
\text { relations; } \\
\text { - Staffing and workforce } \\
\text { planning; } \\
\text { - Performance management; } \\
\text { - Diversity and inclusion. }\end{array}$ & $\begin{array}{l}\text { Chaired and 'owned' by BSI } \\
\text { - Over-arching standard: } \\
\text { Valuing People in } \\
\text { Organizations } \\
\text { - Diversity and social } \\
\text { inclusion } \\
\text { - Learning and development } \\
\text { - Health and Wellbeing }\end{array}$ \\
\hline $\begin{array}{l}\text { Committee } \\
\text { membership }\end{array}$ & $\begin{array}{l}\text { Large corporates and some } \\
\text { academic representation }\end{array}$ & $\begin{array}{l}\text { Employee representative } \\
\text { organizations (ACAS, TUC); } \\
\text { Employers and employer } \\
\text { representative organizations (e.g. } \\
\text { Federation of Small Businesses); } \\
\text { Third sector organizations; } \\
\text { academics; standards specialists; } \\
\text { Professional bodies e.g. CIPD } \\
\text { and UFHRD; Independent } \\
\text { experts. }\end{array}$ \\
\hline $\begin{array}{l}\text { Stated } \\
\text { purpose }\end{array}$ & $\begin{array}{ll}\text { - } & \text { Cost reduction } \\
\text { - } & \text { Minimize error } \\
\text { - } & \text { Conformance }\end{array}$ & 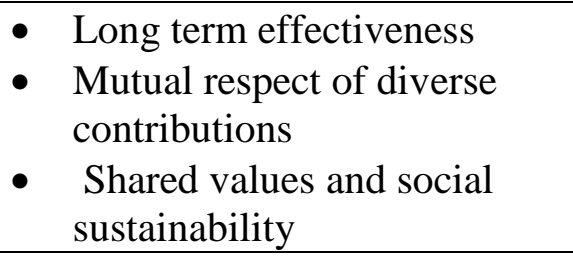 \\
\hline Focus & $\begin{array}{l}\text { - Standardized practices, } \\
\text { systems and terminologies } \\
\text { - Metrics }\end{array}$ & $\begin{array}{l}\text { - Realization and value (actual } \\
\text { and potential) of peoples' } \\
\text { capabilities, skills, } \\
\text { knowledge, experience, } \\
\text { networks, behaviours, } \\
\text { attitudes }\end{array}$ \\
\hline $\begin{array}{l}\text { Published } \\
\text { standards }\end{array}$ & $\begin{array}{l}\text { - Workplace Violence } \\
\text { Prevention and Intervention, } \\
2011 \\
\text { - } \quad \text { Cost-per-hire , } 2012\end{array}$ & $\begin{array}{l}\text { - } \quad \text { Valuing People: } \\
\text { Management System } \\
\text { standard, 2015 } \\
\text { - } \text { Valuing People: Diversity } \\
\text { and Inclusion, } 2017 \\
\end{array}$ \\
\hline
\end{tabular}




\begin{tabular}{|l|l|l|}
\hline & $\begin{array}{l}\text { Performance Management, } \\
2012\end{array}$ & $\begin{array}{l}\text { Valuing People: A Guide to } \\
\text { Learning and Development, } \\
2017\end{array}$ \\
\hline
\end{tabular}

\section{Table 2: ANSI and BSI approach to HR standards}

As an HRD scholar and teacher I was aware that, although HRD vocational education, pedagogy and professional formation processes are organized and undertaken in different ways in various parts of the world (Kuchinke 2003; Watkins and Marsick 2016; Zachmeier and Cho 2014; Cho and Zachmeier 2015) HR standards development is likely to have important consequences for curriculum development, teaching, scholarship and practice and, reflexively, I was aware that this informed my initial motivation and decision to engage in the standards development process.

Currently, HRD pedagogy and curriculum is influenced to some extent by frameworks established by professional bodies, such as the ATD Competency Model (ATD 2017) and SHRM Certification Standards (SHRM 2017) in USA and the CIPD Profession Map (CIPD n.d.) in UK and by emerging perspectives of scholarly organizations such as Academy of Human Resource Development (AHRD) related to standards of ethical and professional conduct (Russ-Eft 2009; Kim, Park, and Kolb 2014). During the process I maintained a self-awareness that the work of national and international standardization bodies focused on HR would likely become an important reference point for curriculum and professional formation and development. HRD influence in standards development processes is important to encourage 'the beginning of something new' (Cotter, 2014) that addresses the problems and dilemmas of standardization (Heras-Saizarbitoria and Boiral 2013; Corbett and Yeung 2008). My involvement was, in part, influenced by my prior experience as a practitioner of working with the IiP standards and my sense of their limitations. During the subsequent three years of working in the standards development group I developed a sense that my engagement, 
and the involvement of others in the HRD field could be influential in challenging the dominance in standardization of a sole focus on performance outcomes and corporate agendas. My concern to promote the values of development at individual and organizational levels was not an isolated perspective and underpinned processes of coalition building and interactions involving micro-power relationships with other participants whereby assumptions about hierarchical authority structures as a basis for standards implementation and reliance on a 'check-do-review' approach to measuring and managing performance could be challenged and reassessed.

Whilst the involvement of those from the HRD field is not a predictor of outcomes in relation to standardization, the analysis summarized in Table 2 shows that an alternative to the rules-based approach is possible. The experience of BSI standardization processes in the HR field illustrates how a pluralist and inclusive approach to standards development incorporating a diversity of 'voices' and perspectives can challenge the dominant vernacular of standardization and offer an opportunity for the development of an alternative approach. My experience of being involved in the standards development process highlighted how inclusive standardization processes require extended debate, discussion, and revision to reflect the different points of view of stakeholders with varying perspectives on the employment relationship. In this specific circumstance the standards development process was slow and the eventual outcomes could not have been predicted (Botzem and Dobusch, 2012; Jacobs, 2013). However, the outcome of the process in UK where my HRD perspective was included, led to a definition of 'value' in relation to those who work on behalf of an organization as "the merit and worth of people due to their unique knowledge, skills and abilities" (BSI 2015). As a result the focus of the British standard is on "the realization and value (actual and potential) of peoples' capabilities to promote long-term 
organizational effectiveness, mutual respect of diverse contributions to organizational effectiveness; shared values and social sustainability" (BSI 2015, p. 10). The British Standard for HR (BS76000, Valuing People - Management System) published in 2015 makes explicit the principle that "people are valued for who they are and not just because they deliver monetary value or money-value equivalents to their organization" (BSI, 2015, p. 10).

In adopting this principles-led approach the BSI standard for Human Resources recognizes and encourages the intrinsic potential of individuals and indicates the importance of trust, openness and continuous organization development in organizational work processes. These assumptions differ from those of the ANSI HR standards where conformance to process consistency and cost reduction are the main focus. The argument advanced here is that an alternative to the dominant rules-based approach was made possible by extensive processes of debate and discussion involved that was informed by HRD perspectives (mine and those of others) as well as those of HRM practitioners and representatives of small business, consultancies, employer representative organizations and the UK CIPD. During these processes agreement was reached that HR standards should extend beyond individual work objectives and shortterm organizational performance in order to acknowledge the importance of sustainable performance and recognise the perspectives of communities within which organizations operate. The BSI standard for HR that was developed from this discursive process resembles the characterization of a principles-led approach. As an academic professional I was aware that consensus on the core values of HRD remains elusive (Hart, Lynham and McLean 2014) but the values adopted by the BSI standard are aligned with those identified by Bates and Chen (2005, p.344) as representative of the 'meaning of work' HRD paradigm which also resembles what has been labelled as a 
commitment-focused HRM approach (Cook, MacKenzie, and Forde 2016; Guinot, Chiva, and Mallén 2016). Such an outcome is not a necessary consequence of HR standardization processes.

In the field of standardization in general, network-based information and exchange forms the basis of processes undertaken by accredited national standardization bodies and represents an important opportunity for those in the HRD field to influence HR standards development (van den Ende, van de Kaa, den Uijl \& de Vries, 2012; Brunsson et al., 2012). All nationally accredited standardization bodies are mandated to encourage widespread involvement and information exchange as a basis for standards development (Botzem et al. 2012; Brunsson, Rasche, and Seidl 2012; HerasSaizarbitoria and Boiral 2013). This expectation is implemented in different ways by national jurisdictions but the potential involvement of HRD practitioners whose organizations might adopt the standards; HRD consultancy and research organizations; professional and scholarly bodies; and academic experts represents an important opportunity for those in the HRD field. I contend that those in the HRD field should take advantage of opportunities for involvement in HR standardisation processes. In making this 'call to action' by HRD scholars and practitioners in standards development processes I argue for a rigorous evaluation of the paradigmatic basis of HR standardization by those involved so that alternative principles for HR standards development are debated and discussed. HRD contributions are not evident in the ANSI HR standards primarily developed through task forces comprising HRM representatives of large corporate organizations and standards specialists (SHRM, 2015). Although my contribution to the drafting process was not the most influential, others played more prominent roles, this involvement highlighted the opportunities for those in the HRD field to influence standardization processes. The achievement of consensus required by 
standards development processes requires willingness by different parties from HRM and HRD fields to make reasonable compromises but the mandate for consensus in standards development processes means that where arguments are voiced by those in the HRD field these should be taken seriously (Botzem and Dobusch 2012).

In addition to involvement in standards development processes, a second opportunity for influence on the development of HR standards arises from the requirement for all new or revised Standards developed or drafted by accredited National Standardization organizations to be made available for public comment before their ultimate publication. The ANSI standards were subject to two rounds of public consultation prior to publication and any member of the general public who has an interest in the content of the Standard can contribute their views (BSI 2017). In the 100 day public consultation process for the first BSI HR standard the European scholarly body, UFHRD participated fully and many of their suggested revisions to the text of the standard were incorporated into the final version of the standard.

Therefore, involvement opportunities designed into standards development by accredited national standardization bodies and the consultation process that is required before new standards are published or existing standards are revised presents the HRD field with opportunities to influence the outcomes of HR standardization processes alongside the perspectives of other stakeholders. However, if those who comprise the HRD field do not participate in the process then standards developers can assume that consensus has been achieved.

\section{Conclusion}

The rationale for this paper is that the process of standardization in the HR field has profound implications for professional identity and practice as well as for curriculum development, pedagogy and education in the HRD field. The influence of 
standards in work organizations is ubiquitous. At both national and international levels, standards are a feature of organizational, professional and social life. Standards are also a defining characteristic of professions in areas such as accounting, legal practice and health and social care (Kim, Park and Kolb 2014). HR Standardization processes commenced in 2009 will ultimately form important reference points for practice, scholarship and professional education and formation in both the HRD and the HRM fields.

The analysis presented in this paper has identified three problems resulting from the traditional 'rules based' approach to standardization (Liu 2014; ICAS 2006; Polacek et al. 2012). First, in spite of the predictive aspirations of those who advocate performance-related outcomes from rules based standards, the achievement of a measurable link between standards implementation and performance outcomes in the HR field is difficult to establish. Second, 'decoupling effects' are likely in circumstances where 'signalling' or 'symbolic adoption' of standards occurs and simultaneous non-adherence or 'token adoption' is evident (Alberga, Tyson, and Parsons 1997; Groysberg, Lin, and Serafeim 2016). Third, predictive and rules-based standards are devised for stable conditions but are inappropriate in a global environment where flexibility, change and adaptability are important for long-term sustainability.An HRD perspective is required to ensure a careful evaluation of the purpose and basis of any emergent HR National standards.

Although the distinction between HRM and HRD remains the subject of scholarly debate, for practitioners in work organizations, there is an acceptance of porous boundaries between the two fields. The implementation of HRD and HRM strategies influences both people management and learning and development at organizational and individual levels (Werner, 2014). This paper represents a 'wake-up 
call' for HRD scholars and practitioners. I argue that those in the HRD field could contribute to standards development through involvement in National standardization committees or task forces and in the consultation processes to which all new and revised standards are subjected. HRD involvement is important in debates about the underlying principles of HR standards and their individual and organizational focus.

Four considerations to this 'call to action' must be taken into account. First, those in the HRD field might wish to argue that HRD is wholly separate to HRM and so standards-setting in the HR field is irrelevant. Although debates continue about the differences between HRD and HRM these exchanges have little resonance for practitioners operating in work organizations. Standardization processes undertaken since 2009 suggest that organizationally based practitioners in both fields rarely recognize the significance of differences between HRM and HRD, something that my involvement in this process led me to acknowledge. The boundaries between the fields of HRM and HRD are likely to remain porous and ill-defined. As a result I argue that the inclusion of HRD perspectives in HR standards setting processes is important.

Second, the view that performance orientated and rules-based standards are preferable to a principles led approach must be acknowledged. Enduring debates about the purposes and values of the HRD field (Bates and Chen 2005; Bates, Chih Chen, and Hatcher 2002) suggest three alternative perspectives towards HRD labelled by Bates et al (2005) as: 'performance focused'; 'meaning of work' and 'learning and development'. The case presented here does not privilege any specific HRD set of values and the outcomes of standards setting procedures and debates cannot be predicted. However, HRD involvement in the discussion is necessary to avoid a position where HR standardization privileges assumptions about the benefits of a performance focused management approach 'by default'. 
The 'insider' account of standardization (Lawless, Sambrook, and Stewart 2012) offered here might form the basis for a third objection. My personal experience represents fluid rather than static 'positions' from 'outsider' to 'insider'. My initial motivation to participate was affected by my prior beliefs about standards and standardization and my involvement in the drafting process highlighted the "messy and uncomfortable realities' (Sriprakash and Mukhopadhyay 2015, p. 234 of such an engagement and the 'micro-workings of power' within the drafting committee and the larger technical committee. This perspective has been combined in this paper with theoretical perspectives drawn from a plurality of scholarly perspectives and by 'grey' and practitioner literatures and other secondary data sources. This paper represents a politically reflexive 'assemblage' of a coherent account of standardization process that, as experienced, was often fragmented, drawn-out and discursive and which other 'actors' might describe in different ways. I aim to combine honest and descriptive reflection with pluralistic and theoretically informed critique and the acknowledgement of the opportunities for the 'beginning of something new' (Cotter 2014).

A further consideration is the focus of this paper on National level standardization rather than International level standardization. However, ISO (international level) standardization occurs through the agency of National Standardization Bodies who form the basis of the Technical Committees at ISO level. Influence in international level standards, therefore, requires prior engagement with National level standardization organizations.

Taken as a whole, this paper responds to the challenge that those in the HRD field must continue to debate professional identity, values and priorities (Bates and Chen 2005; Ruona and Gibson 2004; Sambrook 2008). In making this 'call to action' for HRD engagement with HR standardization processes I argue that contemporary 
developments represent an 'inflection point' for both HRD and HRM. Standards development in the HR field represents an opportunity to advocate for the importance of learning and development at individual, work-group, organizational and societal levels with potential consequences for the development of socially responsible work organizations committed to sustainable individual and organizational level performance.

\section{References}

Agoglia, Christopher P., Timothy S. Doupnik, and George T. Tsakumis. 2011. "Principles-Based versus Rules-Based Accounting Standards: The Influence of Standard Precision and Audit Committee Strength on Financial Reporting Decisions.” Accounting Review 86 (3): 747-67. doi:10.2308/accr.00000045.

Alberga, Trixy, Sham Tyson, and David Parsons. 1997. "An Evaluation of the Investors in People Standard.” Human Resource Management Journal 7 (2): 47-60. doi:10.1111/j.1748-8583.1997.tb00281.x.

Alvesson, Mats. 2003. "Methodology for Close up Studies-struggling with Closeness and Closure." Higher Education 46 (2). Springer: 167-93.

Anderson, Valerie, Thomas Garavan, and Eugene Sadler-Smith. 2014. "Corporate Social Responsibility, Sustainability, Ethics and International Human Resource Development." Human Resource Development International 17 (5). Routledge: 497-98. doi:10.1080/13678868.2014.954187.

Association of Talent Development (ATD). 2017. "The ATD Competency Model". ATD website. Accessed February 72017. https://www.td.org/Certification/Competency-Model

Bates, Reid, and Hsin Chih Chen. 2005. "Value Priorities of Human Resource Development Professionals." Human Resource Development Quarterly 16 (3): 345-68. doi:10.1002/hrdq.1143.

Bates, Reid, Hsin Chih Chen, and Tim Hatcher. 2002. "Value Priorities of HRD Scholars and Practitioners." International Journal of Training and Development 6 (4): 229-339. doi:10.1111/1468-2419.00161.

Bell, E, S Taylor, and R Thorpe. 2002. "A Step in the Right Direction? Investors in 
People and the Learning Organization.” British Journal of Management 13 (2): 161-71. doi:10.1111/1467-8551.00229.

Botzem, Sebastian, and Leonhard Dobusch. 2012. "Standardization Cycles: A Process Perspective on the Formation and Diffusion of Transnational Standards." Organization Studies 33 (5-6): 737-62. doi:10.1177/0170840612443626.

Botzem, Sebastian, Leonhard Dobusch, Jan van den Ende, Geerten van de Kaa, Simon den Uijl, and Henk J de Vries. 2012. "Standardization Cycles: A Process Perspective on the Formation and Diffusion of Transnational Standards." Organization Studies 33 (5-6): 737-62. doi:10.1177/0170840612443626.

Bourne, M, M Franco-Santos, A Pavlov, L Lucianetti, V Martinez, and M Mura. 2008. "The Impact of the Investors in People Standard on People Management Practices and Firm Performance." Management. http://dspace.lib.cranfield.ac.uk/handle/1826/4305.

British Standards Institute (BSI). 2017. "Standards". BSI website. Accessed February 9 2017. https://www.bsigroup.com/en-GB/standards/

BSI. 2015. "New People Management Standard is Published". BSI Website, 30 July. Accessed February 7 2017. https://www.bsigroup.com/en-GB/about-bsi/mediacentre/press-releases/2015/july/New-people-management-standard-is-published-/

BSI. 2015. "BS 76000:2015: Overview". BSI Website. Accessed February 72017. http://shop.bsigroup.com/ProductDetail/?pid=000000000030298954

Brunsson, Nils, Andreas Rasche, and David Seidl. 2012. "The Dynamics of Standardization: Three Perspectives on Standards in Organization Studies." Organization Studies 33 (5-6): 613-32. doi:10.1177/0170840612450120.

Cascio, Wayne F, and John W Boudreau. 2014. "Evidence-Based Management at the Bottom of the Pyramid: Why Human Resources Standards and Research Must Connect More Closely." In The Oxford Handbook of Strategy Implementation, edited by Michael A Hitt, Susan E Jackson, Salvador Carmona, Leonard Bierman, Christina E Shalley, Douglas Michael Wright, Wayne F Cascio, and John W Boudreau. "Oxford University Press." doi:10.1093/oxfordhb/9780190650230.013.12.

Cho, Yonjoo, and Aaron Zachmeier. 2015. “HRD Educators' Views on Teaching and 
Learning: An International Perspective." Advances in Developing Human Resources 17 (2). 145-161.

CIPD. 2015. "From Best to Good Practice HR: Developing The Principles". CIPD Website. Accessed February 92017. https://www.cipd.co.uk/knowledge/strategy/hr/good-practice-report

CIPD. n.d. "CIPD Professional Map". CIPD Website. Accessed February 92017. https://www2.cipd.co.uk/cipd-hr-profession/cipd-hr-profession-map/default.html

Cook, Hugh, Robert MacKenzie, and Christopher Forde. 2016. "HRM and Performance: The Vulnerability of Soft HRM Practices during Recession and Retrenchment." Human Resource Management Journal 26 (4): 557-71. doi:10.1111/1748-8583.12122.

Corbett, Charles J., and Andy C.L. Yeung. 2008. "Special Issue on Meta-Standards in Operations Management: Cross-Disciplinary Perspectives.” International Journal of Production Economics 113 (1): 1-2. doi:10.1016/j.ijpe.2007.02.044.

Cotter, Richard J. 2014. "Reflexive Spaces of Appearance: Rethinking Critical Reflection in the Workplace.” Human Resource Development International 17 (4). Routledge: 459-74. http://10.0.4.56/13678868.2014.932090.

Djelic, Marie Laure, and Frank Den Hond. 2014. "Introduction: Multiplicity and Plurality in the World of Standards." Business and Politics 16 (1): 67-77. doi:10.1515/bap-2013-0034.

Gloster, Rosie, Freddie Sumption, Tom Higgins, and Annette Cox. 2010. Perspectives and Performance of Investors in People : A Literature Review. London. UK Commission for Employment and Skills.

Groysberg, Boris, Eric Lin, and George Serafeim. 2016. "Scandal and Stigma: Does Corporate Misconduct Affect the Future Compensation of Bystander Managers?" In Academy of Management Proceedings, 2016:11631. Academy of Management. Guest, David E., and Christopher Woodrow. 2012. "Exploring the Boundaries of Human Resource Managers' Responsibilities.” Journal of Business Ethics 111 (1): 109-19. doi:10.1007/s10551-012-1438-8.

Guinot, Jacob, Ricardo Chiva, and Fermin Mallen. 2016. "Linking Altruism and Organizational Learning Capability: A Study from Excellent Human Resources 
Management Organizations in Spain.” Journal of Business Ethics 138 (2): 349-64. doi:10.1007/s10551-015-2603-7.

Hamlin, Bob, and Jim Stewart. 2011. "What Is HRD? A Definitional Review and Synthesis of the HRD Domain.” Journal of European Industrial Training 35 (3). Emerald: 199-220. doi:10.1108/03090591111120377.

Heras-Saizarbitoria, Iñaki, and Olivier Boiral. 2013. "ISO 9001 and ISO 14001: Towards a Research Agenda on Management System Standards.” International Journal of Management Reviews 15 (1): 47-65. doi:10.1111/j.14682370.2012.00334.x.

Hernandez, Morela. 2012. "Toward an Understanding of the Psychology of Stewardship" 37 (2): 172-93.

Hoque, K. 2008. "The Impact of Investors in People on Employer-Provided Training, the Equality of Training Provision and the 'Training Apartheid' Phenomenon." Industrial Relations Journal, 43-62. doi:10.1111/j.1468-2338.2007.00473.x.

Hoque, K., Scott Taylor, and Emma Bell. 2005. "Investors in People: Market-Led Voluntarism in Vocational Education and Training.” British Journal of Industrial Relations 43 (1): 135-53. doi:10.1111/j.1467-8543.2005.00348.x.

Hurt, A.C., Lynham, S.A., and McLean, G. 2014. "Investigating the HRD cube and explicating extant paradigms of HRD." European Journal of Training and Development, 38 (4): 323 - 346. http://dx.doi.org/10.1108/EJTD-07-2013-0081

International Organization for Standardization (ISO). n.d. "Benefits of International Standards". ISO website. Accessed February 92017. http://www.iso.org/iso/home/standards/benefitsofstandards.htm

ICAS. 2006. Principles-Based or Rules-Based Accounting Standards? A Question of Judgement. Edinburgh. Institute of Chartered Accountants of Scotland.

ISO. n.d. "ISO/TC 260 Human Resource Management". ISO website. Accessed February 92017.

http://www.iso.org/iso/standards_development/technical_committees/other_bodies /iso_technical_committee.htm?commid=628737

ISO. 2014. "Strategic Business Plans". ISO Strategic Business Plans for Public Review website. Accessed February 92017. 
http://isotc.iso.org/livelink/livelink/fetch/2000/2122/687806/customview.html?fun $\mathrm{c}=11 \& o b j I d=687806 \&$ objAction=browse \&sort=name

Jacobs, K. 2013. "Does HR Need Professional Standards?". HR Magazine. November 12. http://www.hrmagazine.co.uk/article-details/does-hr-need-professionalstandards.

Jacobs. K. 2014. "First British Standard Released for HR Practice". HR Magazine. 14 November. http://www.hrmagazine.co.uk/article-details/first-british-standardreleased-for-hr-practice

Kim, Taesung, Jae-Young Park, and Judith A Kolb. 2014. "Examining the AHRD Standards on Ethics and Integrity Using a Multiple Ethical Paradigms Approach." Human Resource Development Review 13 (3): 293-313. http://hrd.sagepub.com/content/13/3/293.abstract.

Kuchinke, K Peter. 2003. “Comparing National Systems of Human Resource Development: Role and Function of Post-Baccalaureate HRD Courses of Study in the UK and US." Human Resource Development International 6 (3): 285-99.

Lawless, Aileen, Sally Sambrook, and Jim Stewart. 2012. “Critical Human Resource Development: Enabling Alternative Subject Positions within a Master of Arts in Human Resource Development Educational Programme." Human Resource Development International 15 (3): 321-36. http://10.0.4.56/13678868.2012.689214.

Liu, Han Wei. 2014. "International Standards in Flux: A Balkanized ICT StandardSetting Paradigm and Its Implications for the WTO.” Journal of International Economic Law 17 (3): 551-600. doi:10.1093/jiel/jgu034.

McIlvante, A. 2014. "SHRM Stepping Back from HR Standards Work". HREOnline website. December 24. Accessed February 72017. http://blog.hreonline.com/2014/12/24/shrm-stepping-back-hr-standards-work/ Monks, Kathy, Grainne Kelly, Edel Conway, Patrick Flood, Katie Truss, and Enda Hannon. 2013. "Understanding How HR Systems Work: The Role of HR Philosophy and HR Processes." Human Resource Management Journal 23 (4): 379-95. doi:10.1111/j.1748-8583.2012.00207.x.

Murphy, A., and T. N. Garavan. 2009. "The Adoption and Diffusion of an NHRD 
Standard: A Conceptual Framework." Human Resource Development Review 8 (1): 3-21. doi:10.1177/1534484308330019.

Polacek, George, David A. Gianetto, Khaldoun Khashanah, and Dinesh Verma. 2012. "On Principles and Rules in Complex Adaptive Systems: A Financial System Case Study." Systems Engineering 15 (4): 433-47. doi:10.1002/sys.

Reio, Thomas G. 2013. "Exploring the Links between Adult Education and Human Resource Development: Learning, Risk-Taking, and Democratic Discourse.” New Horizons in Adult Education and Human Resource Development 25 (4): 4-11. doi:10.1002/nha3.20042.

Ruona, Wendy E A, and Sharon K Gibson. 2004. "The Making of Twenty-first-century HR: An Analysis of the Convergence of HRM, HRD, and OD." Human Resource Management 43 (1): 49-66.

Russ-Eft, D. F. 2009. "Human Resource Development (HRD) Evaluation and Principles Related to the Public Interest." American Journal of Evaluation 30 (2): 225-31. doi:10.1177/1098214009334677.

Sambrook, Sally. 2008. "Critical HRD: A Concept Analysis.” Personnel Review 38 (1): $61-73$.

Sambrook, Sally, and Hugh Willmott. 2014. "The Rigor of Management Education and the Relevance of Human Resource Development: Natural Partners or Uneasy Bedfellows in Management Practice?" Management Learning 45 (1): 39-56. http://mlq.sagepub.com/content/45/1/39.

Society for Human Resource Management (SHRM). 2012. "ANSI Approves Performance Management Standard". December 18. SHRM Website. Accessed February 7 2017. https://www.shrm.org/about-shrm/press-room/pressreleases/pages/ansiapprovesperformancemanagementstandard.aspx

SHRM. n.d. "Human Resource Management Standards". SHRM/PACE website. Accessed February 7 2017. http://shrm.pace.edu.vn/en/KnowledgeCenter/90/Human-Resource-Management-Standards

SHRM. 2017. "About the Comptency Model". SHRM Website. Accessed February 9 2017. https://www.shrm.org/learningandcareer/competencymodel/pages/default.aspx 
Smith, Simon M, Peter Stokes, and John F Wilson. 2014. "Exploring the Impact of Investors in People.” Employee Relations 36 (3): 266-79. doi:10.1108/ER-092012-0064.

Sriprakash, A. and Mukhopadhyay, R. 2015. "Reflexivity and the politics of knowledge: researchers as 'brokers' and 'translators' of educational development. Comparative Education 51 (2): 231-246, DOI: $10.1080 / 03050068.2014 .996027$

Swann, Peter G. M. 2010. "The Economics of Standardization: An Update.” http://gala.gre.ac.uk/6925/.

Thite, Mohan. 2013. "Ethics and Human Resource Management and Development in a Global Context: Case Study of an Indian Multinational." Human Resource Development International 16 (1). Routledge: 106-15. doi:10.1080/13678868.2012.737691.

Ulrich, Dave, Jon Younger, Wayne Brockbank, and Michael D Ulrich. 2013. "The State of the HR Profession.” Human Resource Management 52 (3): 457-71.

Uzumeri, Mustafa V. 1997. "ISO 9000 and Other Metastandards: Principles for Management Practice?" Academy of Management Executive 11 (1). Academy of Management: 21-36. 10.5465/AME.1997.9707100657.

van den Ende, Jan, Geerten van de Kaa, Simon den Uijl, and Henk J de Vries. 2012. "The Paradox of Standard Flexibility: The Effects of Co-Evolution between Standard and Interorganizational Network." Organization Studies 33 (5-6): 70536. doi:10.1177/0170840612443625.

Waite, Alina M. 2013. “Leadership's Influence on Innovation and Sustainability for HRD." European Journal of Training and Development 38 (1/2): 38-59. doi:10.1108/EJTD-09-2013-0094.

Watkins, Karen E. 2016. "A History of the Academy of Human Resource Development: An Introduction." Advances in Developing Human Resources 18 (4): 431-38.

Watkins, Karen E, and Victoria J Marsick. 2016. "Development of Academic Programs in Human Resource Development in the United States." Advances in Developing Human Resources 18 (4). SAGE Publications Sage CA: Los Angeles, CA: 467-80. Webster, L. n.d. "Using ANSI Human Resource Standards to Create Business 
Advantage in the Workplace". Society for Standards Professionals (SES) Webinar Slides. Accessed February 7 2017. http://www.sesstandards.org/associations/3698/files/SES_Webinar_Slide_February2013\%20Webster.pdf

Werner, Jon M. 2014. “Human Resource Development $\neq$ Human Resource Management: So What Is It?” Human Resource Development Quarterly 25 (2): 127-39. doi:10.1002/hrdq.21188.

Westhuizen, C Van Der, and LJ Van Vuuren. 2007. "Human Resource Management as a Profession in South Africa: Practitioners' Perspectives." Resource Management 1 (2): 1-12. doi:10.4102/sajhrm.v1i2.13.

Zachmeier, A. \& Cho, Y. (2014). Taking stock of the literature on HRD education. European Journal of Training and Development 38 (4), 347 - 363. doi: http://dx.doi.org/10.1108/EJTD-07-2013-0080

Zachmeier, A., Cho, Y. and Kim, M. (2014). The same but different: HRD master's programmes in the United States. Human Resource Development International, 17 (3): 318-338. 